\title{
Equity-based Crowdfunding*
}

\author{
Mónika Kuti-Zsolt Bedő - Dorottya Geiszl
}

This paper presents the latest results of international research on equity-based crowdfunding, and thus - according to the authors' current knowledge - fills a gap in the Hungarian literature. Equity-based crowdfunding offers a fundraising opportunity through online platforms for small and medium-sized enterprises seeking alternative forms of funding for growth opportunities and innovation in this digital age. Investors interested in risk-adjusted financial return have several methods available to handle capital market friction and agent costs in the context of "crowdfunding". Information signals on entrepreneurial quality are essential for seasoned investors when making capital allocation decisions in a crowdfunding campaign. In addition to the national legislative framework, platforms have many different rules, techniques and cultural norms that attempt to handle capital market imperfections.

Journal of Economic Literature (JEL) codes: F36, G19, 016

Keywords: equity crowdfunding, financial innovation, start-up financing

\section{Introduction}

Resources intermediated via information technologies open the door for new types of business models and roles. Online exchange, sharing and cooperation between Internet users allows entrepreneurs to recognise opportunities, control resources and create capacity through crowdsourcing, marketing (social brand and word-ofmouth) and crowdfunding (Shneor - Flåten 2015).

This paper focuses specifically on equity-based crowdfunding from among the many different business models available and presents its complex theoretical framework. The appearance of Hungary's first crowdfunding portal for equity

* The views expressed in this paper are those of the author(s) and do not necessarily reflect the offical view of the Magyar Nemzeti Bank.

Mónika Kuti is an assistant professor at the Faculty of Economics of the University of Pecs.

E-mail: kutim@ktk.pte.hu

Zsolt Bedő is an assistant professor at the Faculty of Economics of the University of Pecs.

E-mail: zsoltbedo@ktk.pte.hu

Dorottya Geiszl is a student at the Faculty of Economics of the University of Pecs.

E-mail: dorottya.geiszl@gmail.com

This paper was written with support from the EFOP-3.6.1-16-2016-00004 Institutional Developments Fostering Intelligence Specialisation tender.

The Hungarian manuscript was received on 19 March 2017.

DOI: http://doi.org/10.25201/FER.16.4.187200 
purposes (tokeportal.hu) attests to the topic's local relevance and its inherent business opportunities.

\section{Equity-based crowdfunding}

The shift in corporate funding towards cyberspace, the paradigm change seen in recent years and the shift of collective capital formation towards the digital realm is paving new paths. Equity financing offers the opportunity for early-stage fundraising and for bridging the funding gap for young, innovative startups. These financial innovations open the door for startups to obtain funding even if capital markets are not functioning. In the wake of the global economic crisis, business angels and venture capitalists have increased their investment activity and their preference has shifted to later-stage investments (Block - Sandner 2009). This trend has highlighted the timeliness and opportunities offered by equity-based funding, opening up new directions for research in the international literature. Equity-based crowdfunding (hereinafter: ECF) is likely to create great challenges for business angels and venture capitalists in the near future (Vulkan et al. 2015). Equity-based crowdfunding consists of entrepreneurs publishing open calls online for the sale of their equity shares in the hopes of attracting a large number of investors. The calls and investments take place through online platforms which provides tools such as the legal background, pre-screening and the handling of financial transactions. Equity-based crowdfunding is a model where investors acquire a stake in the company in the form of a share or share-like agreement (such as profit-sharing). Equity-based crowdfunding involves the sale of securities and is therefore significantly influenced by the legal environment of the host country (Bradford 2012).

In terms of the choice between traditional bank financing and crowdfunding, the latter offers financial benefits such as market feedback, product validation and community impacts. Imperfect information and moral hazard also affect companies' choice between the available business models of crowdfunding. In case of equitybased crowdfunding versus donation-based crowdfunding, financial return is important for investors alongside companies' future capacity to generate cash flow. In reward-based crowdfunding, backers tend to look at whether the idea's pitcher will be able to create and deliver the prepurchased product. For large-scale projects, the campaign-starting companies prefer equity crowdfunding and investors also factor in long-term profit; by contrast, the minimum threshold may be difficult to achieve with rewards-based crowdfunding in campaigns that require a high amount, so this format is generally preferred for smaller value, high-quality projects. If a product can reach a large customer base, reward-based crowdfunding enabling pre-purchases is preferred, while profit-sharing-based models are preferred for special niche products (Miglo 2016). 


\section{Capital market imperfections}

The problem of information asymmetry is a central issue in equity-based crowdfunding. Researchers are actively investigating the correlations between the disclosure of information and successful fundraising. Startups send different signals to angel investors and venture capitalists than to small investors. Small investors are less sophisticated in terms of their financial knowledge and experience compared to venture capitalists, who have extensive knowledge on startups and the founding teams' valuation (Freear et al. 1994). Not every signal on startup quality is able to effectively handle information asymmetry. The effectiveness of signals depends on how perceivable they are and their cost, in other words how much investors take notice of them and understand the messages, and also depends on the costs of producing the signals not exceeding their benefits, in other words, they must be structured in such a way that dishonest signals do not pay (Connelly et al. 2011). Ahlers et al. (2015) investigate what project signals and entrepreneur quality attributes most spurred investors to pledge their financial resources in the context of equity-based crowdfunding. They found that projects that signal higher entrepreneurial quality and have perceptible characteristics are more likely to attract funding; the less detailed the information on the link between the offered business share and financial forecasts, i.e. the higher the uncertainty, the more careful potential investors will be when evaluating the startup; social capital and intellectual capital barely have an impact on campaign success. The hard signals issued by entrepreneur are discounted by investors while the hard information from investors significantly shapes campaign success; meanwhile, soft information from both entrepreneurs and investors reinforce network impacts (Estrin - Khavul 2016).

The fraction of equity retained by the entrepreneur or overcapitalisation is typically interpreted as a sign of entrepreneurial intent and a greater fundraising opportunity (Leland - Pyle 1977). If the long-term objective of fundraising is growth in the context of equity crowdfunding, the startup must strive to retain control in the course of issuance. The proposed proportion of equity is generally disclosed on the platforms. Retaining equity can essentially be interpreted as a perceivable signal (Ahlers et al. 2015). On the one hand, entrepreneurs who offer a larger portion of their startup through the platform are less likely to attract potential investors; on the other hand, the success rate is higher for entrepreneurs with larger social networks, as this decreases uncertainty and increases visibility (Vismara 2015b).

Researchers are also investigating information asymmetry and the question of location. Seed-stage equity-based and platform-based interregional trading creates opportunities for startups, investors and legislators, contributing to more effective capital allocation. Angel investments are geographically localised; early-stage investors focus on local transactions. Although there is home bias in equity-based crowdfunding that characterises investors who are similar to business angels, there 
is no such behaviour among sufficiently diversified investors (Hornuf - Schmidt 2016). A common explanation for the absence of remote angel investments is information asymmetry. Although the Internet breaks down certain types of information constraints, it is incapable of transmitting face-to-face interactions such as the founding team's grit, determination, interpersonal dynamics, and trustworthiness (Agrawal et al. 2015). The face-to-face personal communication characteristic of angel investors and venture capitalists (Moritz et al. 2014) is replaced on these platforms by pseudo-personal communication.

Equity-based crowdfunding syndicates made up of leading investors are able to tackle the issue of information asymmetry. These business formations present the transactions to masses of potential backers (Agrawal et al. 2015) and link the faceto-face due diligence and monitoring that is characteristic of the off-line realm with online global access. The introduction of syndicates in equity crowdfunding is a relatively new phenomenon, available on AngelList since 2013. This platform allows individuals, angel groups and private equity funds to form syndicates and boasts a far higher rate of successful syndicated transactions compared to non-syndicated transactions. Venture capitalists therefore tend to prefer the syndicate strategy to increase the number of incoming transactions, improve brand reputation and provide sound arguments to their key partners with a view to concluding effective agreements (Coppey 2016). A syndicate is essentially a pre-screening mechanism prior to the subsequent non-syndicated investment stages. Syndicate leaders are generally well-connected through investment channels and business opportunities, which creates conflict of interest with unsophisticated small investors seeking to invest in startups. There is thus a trade-off in syndicated equity crowdfunding between access to deals and conflict of interest (Itenberg - Smith 2017). The authors demonstrated that syndicated investment offer rounds are riskier, yield slower return, and startups in which a syndicate leader invested earlier perform worse.

In the case of equity-based crowdfunding, a kind of counterselection resulting in a sub-optimal balance can be observed, i.e. a process in which the price and quantity of products and services change within a given market because one counterparty possesses information that the other party cannot obtain even at a reasonable cost. According to Agrawal et al. (2015), neither ordinary investors nor startup founders are able to correct information asymmetry at a reasonable cost in the context of crowdfunding. Ordinary investors typically lack the time, money and expertise to be involved in the daily management and supervision of the startups they fund. On the other hand, startup founders have a better understanding of what they are doing and their market prospects, but have limited resources to communicate with the investors, to widely disseminate information and to prepare detailed financial reports. Moral hazard is when the party which incurs the costs has to assume disproportionate risk. Once a crowdfunding campaign ends, backers do not have 
effective means to force startup founders to perform in line with the promised conditions. At this point, the acquired equity belongs to the startup, the bargaining position has shifted between opportunistic startups and investors, while ordinary investors assume the risk of loss.

The examination of campaign updates introduced a dynamic approach into research following the static analysis of information asymmetry. Startups can increase the probability of their equity-based crowdfunding campaign succeeding by disclosing up-to-date information. It is thus useful to know which types of updates are effective. Updates related to the number of investments made by the crowd and the amount of investments collected by startups have a positive impact on campaign success with a few days' delay (Block et al. 2016). According to the authors, this impact increases with the number of words featured in the updates, but decreases in parallel with the number of updates. They pointed out that updates related to the startup team (qualifications, age and personal interests), the business model (expected market, business idea, future business orientation and expansion expectations), co-creation projects and product development no longer have a major impact on the level of success. By contrast, updates on new funds (e.g. from angel investors, venture capitalists or tenders), the development of the business related to increases in sales revenues and favourable customer feedback as well as the promotional campaigns led by the startup, with networking taking place on social media, have a positive impact. Businesses release significantly more updates during the funding campaign than afterwards and publish more information if the campaign did not reach the funding objective or if the remaining funding period is short (Dorfleitner et al. 2017). According to Dorfleitner et al., businesses use some linguistic tools in their updates that strengthen group identity and group cohesion, and the probability of updates is higher when there is strong competition among the crowdfunding campaigns running in parallel.

The success rate is higher for those businesses that are also supported by professional investors (business angels and venture capitalists) and which obtained some grant money, or have protected their intellectual capital in the form of patents, trademarks or copyrights - pointed out Ralcheva and Roosenboom (2016), who also emphasised that if the business hired a consulting body, appointed nonexecutive directors or involved consultancy firms, or if the owner intends to keep a larger share of the business after the funding, a successful campaign is more probable. According to some other studies, the campaign's success is determined by the pre-filtered campaign characteristics and the private and public networks, i.e. the investment decision criteria applied by traditional venture capitalists and angel investors are less relevant (Lukkarinen et al. 2016).

Early supporters play a key role in the success of crowdfunding campaigns on donation-based platforms (Burtch et al. 2013), reward-based platforms (Colombo 
et al. 2015) and debt-based platforms (Zhang - Liu 2012). Empirical evidence to support this in the case of equity-based crowdfunding has been missing for a long time. On equity-based crowdfunding platforms, the names of individual investors are public and immediately accessible for every single offering which, in turn, affects the behaviour of future investors. Creating momentum in an early stage is a success factor, as the information can be evaluated based on the list of previous investments of early supporters which may convince future investors. Those investors who made their profile public often have higher qualifications, more project specific industry experience and a longer list of investments made through the platform. Additionally, their offering share compared to other investors is larger during the initial days of the campaign and then declines over time (Vismara 2015a). According to the author, information cascades are being formed as the presence of investors with a public profile attracts additional investors as the result of the "success brings more success" process. The psychological concept of observation-based social learning (Bandura 1977) appears in the financial literature as information cascades (Welch 1992). Two conditions must exist for the information cascade to occur: uncertainty and sequentiality (Bikhchandani et al. 1992). Uncertainty appears more on the demand side of equity-based crowdfunding, where investors are less capable of overcoming information asymmetry. In this case, the signals sent by additional investors, i.e. the mass impact, becomes significant. In the course of crowdfunding, subsequent investors learn from observing the behaviour of previous supporters.

The dynamics of crowdinvesting is L-shaped on the platforms operating on "first come first served" basis, while it is U-shaped on the platforms operating on "sealed offer and secondary price auction" basis. (Hornuf - Armin 2015). Therefore, we have evidence supporting the idea that investors make their decisions based on the information updates provided by the entrepreneur and based on the investment behaviour and comments of other crowd investors. Campaign attributes, the level of investor sophistication, the process of granting funds, herd behaviour and stock exchange volatility determine the extent to which investors are willing to pay for the cash flow rights of startup businesses (Hornuf - Neuenkirch 2015). It is difficult to tell to what extent crowdinvestors become small business angels: sometimes they invest together with professional investors, but sometimes they are the competitors of business angels (Hornuf-Schwienbacher 2014).

In terms of their composition, crowd investors cannot be considered as a homogeneous community. Wallmeroth (2016) revealed that strategic investors investing a larger part of their own assets are less likely to become investors who later return to the platform and are more likely to invest in businesses that will not go bankrupt after the campaign. In his opinion, it is likely that investors offering large amounts are sophisticated, professional investors as opposed to the crowd of less sophisticated investors sporadically investing small amounts. According to 
Brown and Davis (2017), equity crowdfunding is characterised in general by the "all or nothing" funding style, the scarcity of investor profit and the crowd of noncooperating investors.

In the case of equity crowdfunding, nonfinancial motivations are not typical, and investors are more likely to redeem after the campaign their intention to make a financial commitment expressed during the campaign than in the case of the reward-based model (Cholakova - Clarysse 2014). As for crowdfunding providing financial return, crowdinvestors are typically young men with degrees motivated by the acquisition of business share and by excitement (Daskalakis - Yue 2017). On the markets of equity crowdfunding, 93 per cent of investors are men, which can be explained more by the gender difference related to risk avoidance than by the differences in terms of excessive self-confidence (Hervé et al. 2016). One interesting observation is that the balanced presence of genders is the highest for equity-based crowdfunding compared with all other forms of business funding, and furthermore, that gender determines the nature of the relationship between demand and offer of capital: According to Vismara et al. (2016), projects of woman-led businesses have twice as many female investors than those helmed by men. The authors showed that although the great majority of investors are men, women invest 34 per cent more in general.

The literature also addresses the performance indicators after the campaign. One year after a successful campaign, the businesses' revenues and the growth rate of their sales increased, which shows a positive link with the large number of investors during the campaign, while the profit dropped in general. According to Décarre and Wetterhag (2014), these trends resemble the one seen when business ventures are investing in companies. They also emphasise that a PR effect can be felt, resulting from the fact that these businesses also use the campaigns for marketing and promotional purposes. Based on their research of equity crowdfunding platforms in the UK between 2011 and 2015, Signori and Vismara (2016) found that only 10 per cent of the businesses failed, and 30 per cent of them were able to involve additional funding with one or more seasonal share issuances, while investors' average expected return was 8.8 per cent.

\section{Equity-based crowdfunding platforms}

Social networks and online platforms create new opportunities to raise funds for businesses and enable nonprofessional investors to place their funds without the use of financial intermediary systems. The acceleration and scaling of early funding opportunities within business funding schemes via Internet platforms can be exploited, taking account of the given regulatory system, which creates a balance between capital formation and investor protection. The platform is an architecture 
which enables the exploitation of the signals and network effects in a reduced transactional cost environment (Estrin - Khavul 2016). The transactional interface for ECF must provide the legal background and the pre-screening of businesses, and allow financial transactions to be made (Ahlers et al. 2015). Intragroup and intergroup moderation is possible on the platform acting as an intermediary interface (Belleflamme et al. 2015; Viotto 2015). ECF is a multiple-phase process where targeted communication is needed for business ideas to be convincing on the platform and for investors.

According to Löher (2016), the three important areas of the intermediary role include a) project pre-screening, where the platform relies on its own networks thanks to access to deal offers, which has the objective of reducing the cost of dealseeking; b) the use of standardised contracts that comply with the legal background; and c) communication to reduce information asymmetry and promote a uniform campaign strategy. These platforms essentially search, assess and structure investment opportunities.

Brown et al. (2016) formulated the following correlations in terms of crowdfunding and platform efficiency:

1. The equity-based crowdfunding platform must simultaneously ensure that entrepreneurs can lawfully raise capital, and that investors can lawfully access investment opportunities.

2. It is more naïve investors narrow-mindedly following signals and basing their decisions on mass wisdom and not sophisticated investors who are needed for the equity-based crowdfunding platform to be efficient.

Lower quality businesses with a smaller social network are forced to turn to the crowd if they are unable to obtain funds from friends, family members, business angels or from venture capitalists through traditional early-stage funding. To reduce counter selection and moral hazard, in addition to legislation, various platform rules, self-regulation forms, technical features and cultural norms were born, which influence what quality and what types of startups are attracted by the platform. Investment ceilings, fundraising ceilings, limited disclosure obligations, platform investments, crowd audits, additional disclosures and performance transparency, and milestone-based financing are the rules and methods that minimise the chance of market failure (Catalini et al. 2016). The differentiating characteristics of high quality startup businesses and the renowned portals functioning as intermediaries may represent the way out of the Lemons Problem (Ibrahim 2015). 
The platforms channel the flow of investments with standardised contracting practice. The platforms make various business offers for the rights to shareholder's equity, profit sharing and future share capital. The offering of non-equity securities is aimed at short-term profit sharing not including shareholder rights. In parallel, the platform also discloses a timing for the future investment rounds and strives to prevent that businesses maintain a costly, long-term relationship with a great number of small investors. The rights to future equity securities offered on the platform last until the occurrence of some future investment event. Future equity capital offers postpone the acquisition of shareholder's rights until the point when the high-growth startup becomes the target of acquisition, IPO or risk capital financing when crowd investors receive their ownership share. In the meantime, crowd investors do not have shareholder's rights, which would entail a number of costly, time-consuming risks and obligations. The link between the features of the early stage startup financing and the transparent investor agreement comes from the Simple Agreement for Future Equity, SAFE, as a deferred equity instrument. Another solution for the same issue is the KISS or Keep It Simple Security, which is essentially a convertible bond according to which the startup business promises the investor to repay the capital with some interest. KISS turns into a property right once the startup reaches certain milestones, such as acquisition, IPO or the involvement of risk capital. Therefore, the difference between KISS and SAFE is that if the investment is not converted into a property right, then in case of SAFE, the investors lose their capital while in the case of KISS, they gain it back through debt service. According to Wroldsen (2017), there are great opportunities in these two simplified contracting forms, but interestingly investors benefit more from the collective protection provided by social media than from the formalised contractual rights.

On the German crowdfunding market, the subordinated loan providing profit sharing became dominant as an investment form. According to Klöhn et al. (2016), the most recent trends include that the minimum maturity time went from 4 years to 6-8 years, lately offering fixed interest payment, and investors are also entitled to profit sharing. The number of contracts granting the right to share in exit revenues increased recently, while veto rights have been discontinued, and dilution is now possible for next round investments. On German equity crowdfunding platforms, crowd investors greatly depend on venture capital funds because they do not hold any share capital in the businesses. Such venture capital funds have a vested interest in crowding out small investors through their mezzanine financing contracts; in response to this trend, the platforms created contracts that promote the coexistence of these two groups (Hornuf-Schmitt 2016). 


\section{Conclusions}

In recent years, equity-based crowdfunding platforms started to emerge once the legislative and regulatory environment had been created. Compared to other crowdfunding business models, investors are driven by financial return and entrepreneurs come up with larger investment projects compared to the average project size of reward-based crowdfunding. A number of success factors have been identified, including signs of strong entrepreneurial skills, the internal proportions of business share offering, the retention of ownership, the availability of hard information on investors, the size of the entrepreneurs' social networks and updates identifying future growth opportunities. When creating equity-based crowdfunding platforms, attention must be paid to the concordance of pre-screening, deal offering and the processes defined by the standardised contracts, compliance with the regulatory environment and the consideration of switching effects between network effects strengthening platform reputation. Off-line investment agents have a beneficial effect on the platforms operating in the given region. Striving to establish best practices requires constant innovation which can be observed in the case of experiments with syndicate strategies and also in the case of the evolution of the various securities and rights serving the reduction of conflict of interest between crowd investors and sophisticated investors.

The ever increasing development of digital technologies, blockchain and bitcoins with the so-called Initial Coin Offering deals propose new directions in the world of business investments through platforms the analysis of which goes far beyond the framework of this study.

\section{References}

Agrawal, A. - Catalini, C. - Goldfarb, A. (2015): Are Syndicates the Killer App of Equity Crowdfunding? MIT Sloan Research Paper No. 5126-15; Rotman School of Management Working Paper No. 2569988. http://dx.doi.org/10.2139/ssrn.2569988

Ahlers, G.K.C. - Cumming, D.J. - Guenther, C. - Schweizer, D. (2015): Signaling in Equity Crowdfunding. Entrepreneurship Theory and Practice, 39(4): 955-980. https://doi. org/10.1111/etap.12157

Bandura, A. (1977): Social Learning Theory. Englewood Cliffs, NJ: Prentice Hall.

Belleflamme, P. - Omrani, N. -Peitz, M (2015): The Economics of Crowdfunding Platforms. Information Economics \& Policy, 33 (Dec.): 11-28. https://doi.org/10.1016/j. infoecopol.2015.08.003 
Bikhchandani, S. - Hirshleifer, D. - Welch, I. (1992): A Theory of Fads, Fashion, Custom, and Cultural Change as Informational Cascades. Journal of Political Economy, Vol. 100, No. 5 (October): 992-1026. https://doi.org/10.1086/261849

Block, J.H. - Hornuf, L. - Moritz, A. (2016): Which Updates During an Equity Crowdfunding Campaign Increase Crowd Participation? https://doi.org/10.2139/ssrn.2781715

Block, J. - Sandner, P. (2009): What is the Effect of the Financial Crisis on Venture Capital Financing? Empirical Evidence from US Internet Start-ups. Venture Capital An International Journal of Entrepreneurial Finance, Vol. 11: 295-309. https://doi. org/10.1080/13691060903184803

Bradford, S.C. (2012): Crowdfunding and the Federal Securities Laws. Columbia Business Law Review, Vol. 2012, No. 1.

Brown, D.C. - Davies, S.W. (2017): Financing Efficiency of Securities-Based Crowdfunding. https://doi.org/10.2139/ssrn.2692828

Brown, D.C. - Davies, S.W. (2016): Equity Crowdfunding: Harnessing the Wisdom of the Crowd. https://pdfs.semanticscholar.org/6382/9449bc90e899e84ee649a31fd2a87d326476.pdf

Burtch, G. - Ghose, A. - Wattal, S. (2013): An Empirical Examination of the Antecedents and Consequences of Contribution Patterns in Crowd-funded Markets. Information Systems Research, Vol. 24, No. 3: 499-519. https://doi.org/10.1287/isre.1120.0468

Catalini, C. - Fazio, C. - Murray, F. (2016): Can Equity Crowdfunding Democratize Access to Capital and Investment Opportunities? MIT Innovation Initiative Lab for Innovation Science and Policy Report. https://doi.org/10.2139/ssrn.2780551

Cholakova, M. - Clarysse, B. (2015): Does the Possibility to Make Equity Investments in Crowdfunding Projects Crowd Out rewards-based Investments? Entrepreneurship Theory and Practice, Vol. 39: 145-172. https://doi.org/10.1111/etap.12139

Colombo, M.G. - Franzoni, C. - Rossi Lamastra, C. (2015): Internal Social Capital and the Attraction of Early Contributions in Crowdfunding. Entrepreneurship Theory and Practice, Vol. 39, No. 1: 75-102. https://doi.org/10.1111/etap.12118

Connelly, B.L. - Certo, S.T. - Ireland, R.D. - Reutzel, C.R. (2011): Signaling Theory: A Review and Assessment. Journal of Management Vol. 37: 39-67. https://doi. org/10.1177/0149206310388419

Coppey, L. (2016): From Value-Added VCS to Equity Crowdfunding Syndicates: the New Platforms of the Venture Capital Industry. MIT Sloan Management Department. http:// hdl.handle.net/1721.1/104539. 
Daskalakis, N. - Yue, W. (2017): User's Perceptions of Motivations and Risks in Crowdfunding with Financial Returns. https://doi.org/10.2139/ssrn.2968912

Décarre, M. - Wetterhag, E. (2014): Uncovering the Outcomes of Equity Crowdfunding: Post-Funding Outcomes of Equity Crowdfunded Firms in Europe. https://doi.org/10.2139/ ssrn.2545276

Dorfleitner, G. - Hornuf, L. - Weber, M. (2017): Dynamics of Investor Communication in Equity Crowdfunding. Max Planck Institute for Innovation \& Competition Research Paper No. 17-06. https://doi.org/10.2139/ssrn.2962951

Estrin, S. - Khavul S. (2016): Academy of Management of Proceedings (Meeting Abstract Supplement) 13036.

Freear, J. - Sohl, J.E. - Wetzel Jr., W.E. (1994): Angels and Non-Angels: Are there Differences? Journal of Business Venturing, Vol. 9: 109-123. https://doi.org/10.1016/08839026(94)90004-3

Hervé, F. - Manthé, E. - Sannajust, A. - Schwienbacher, A. (2016): Investor Motivations in Investment-Based Crowdfunding. https://econpapers.repec.org/paper/haljournl/hal01452026.htm

Hornuf, L - Schmitt, M. (2016): Success and Failure in Equity Crowdfunding. CESifo DICE Report Vol. 14, No. 2: 16-22.

Hornuf, L. - Neuenkirch, M. (2015): Pricing the Value of Cash Flow Rights in Crowdinvesting: An Analysis of Innovestment Backers.

Hornuf, L. - Schmitt, M. (2016): Does a Local Bias Exist in Equity Crowdfunding? Max Planck Institute for Innovation \& Competition Research Paper No. 16-07. https://doi.org/10.2139/ ssrn. 2801170

Hornuf, L. - Schwienbacher, A. (2014): Crowdinvesting - Angel Investing for the Masses? Handbook of Research on Venture Capital: Volume 3. Business Angels, Forthcoming. http:// ssrn.com/abstract=2401515. Downloaded: 18 August 2016.

Hornuf, L. - Schwienbacher, A. (2015): Funding Dynamics in Crowdinvesting. https://ideas. repec.org/p/zbw/vfsc15/112969.html. Downloaded: 18 August 2016.

Ibrahim, D.M. (2015): Equity Crowdfunding: A Market for Lemons? Minnesota Law Review, Vol. 100; William \& Mary Law School Research Paper No. 09-292. https://doi.org/10.2139/ ssrn. 2539786

Itenberg, O. - Smith, E.E. (2017): Syndicated Equity Crowdfunding: The Trade-Off between Deal Access and Conflicts of Interest. Simon Business School Working Paper No. FR 17-06. https://doi.org/10.2139/ssrn.2933822 
Klöhn, L. - Hornuf, L. - Schilling, T. (2016): Financial Contracting in Crowdinvesting: Lessons from the German Market. https://doi.org/10.2139/ssrn.2839041

Leland, H.E. - Pyle, D. (1977): Informational Asymmetries, Financial Structure and Financial Intermediation. Journal of Finance, Vol. 32: 371-387. https://doi.org/10.2307/2326770

Löher, J. (2016): The Interaction of Equity Crowdfunding Platforms and Ventures: An Analysis of the Preselection Process. Venture Capital, Forthcoming. https://ssrn.com/ abstract $=2875673$.

Lukkarinen, A. -Teich, J.E. - Wallenius, H. - Wallenius, J. (2016): Success Drivers of Online Equity Crowdfunding Campaigns. Decision Support Systems, Vol. 87: 26-38. https://doi. org/10.1016/j.dss.2016.04.006

Miglo, A. (2016): Crowdfunding: Balancing Imperfect Information and Moral Hazard Considerations. https://doi.org/10.2139/ssrn.2793631

Moritz, A. - Block, J.H. - Lutz, E. (2014): Investor Communication in Crowdfunding: A Qualitative-Empirical Study. http://ssrn.com/abstract=2462282. Downloaded: 18 August 2016.

Ralcheva, A. - Roosenboom, P. (2016): On the Road to Success in Equity Crowdfunding. https://doi.org/10.2139/ssrn.2727742

Shneor, R. - Flåten, B. (2015): Opportunities for Entrepreneurial Development and Growth through Online Communities, Collaboration and Co-Creation, In: Kaufmann, H.R. and Shams, R.: Entrepreneurial challenges in the 21st century, Chapter 11, Basingstoke UK: Palgrave Macmillan. http://ssrn.com/abstract=2684712. Downloaded: 18 August 2016.

Signori, A. - Vismara, S. (2016): Returns on Investments in Equity Crowdfunding. https:// doi.org/10.2139/ssrn.2765488

Vismara, S. (2015a): Information Cascades Among Investors in Equity Crowdfunding. https:// doi.org/10.2139/ssrn.2589619

Vismara, S. (2015b): Equity Retention and Social Network Theory in Equity Crowdfunding. https://doi.org/10.2139/ssrn.2654325

Vismara, S. - Benaroio, D. - Carne, F. (2016): Gender in Entrepreneurial Finance: Matching Investors and Entrepreneurs in Equity Crowdfunding. Forthcoming in Link, A. (eds.): Gender and Entrepreneurial Activity. Cheltenham, UK: Edward Elgar. https://ssrn.com/ abstract $=2833946$

Vulkan, N. - Astebro, T.B. - Fernandez, S.M. (2015): Equity Crowdfunding: A New Phenomena. Saïd Business School WP 2015-21. https://doi.org/10.2139/ssrn.2700236 
Wallmeroth, J. (2016): Investor Behavior in Equity Crowdfunding. https://doi.org/10.2139/ ssrn.2881394

Welch, I. (1992): Sequential Sales, Learning, and Cascades. Journal of Finance, Vol. 47: 695-732. https://doi.org/10.1111/j.1540-6261.1992.tb04406.x

Wroldsen, J. (2017): Crowdfunding Investment Contracts. 11 Virginia Law \& Business Review (Spring, Forthcoming). https://ssrn.com/abstract=2844771

Zhang, J. - Liu, P. (2012): Rational Herding in Microloan Markets. Management Science, Vol. 58, No. 5: 892-912. https://doi.org/10.1287/mnsc.1110.1459 